\title{
PENGARUH TEORI THE BIG FIVE-PERSONALITY TERHADAP KINERJA PEGAWAI BADAN PENANGGULANGAN BENCANA DAERAH DIY
}

\author{
Neni Poniarsih \\ Program Pascasarjana Magister Manajemen Universitas Jenderal Soedirman Purwokerto \\ Fakultas Ekonomi dan Bisnis Magister Manajemen Universitas Jenderal Soedirman \\ Purwokerto \\ *Email corresponding author: neni.poniarsih@mail.ugm.ac.id
}

\begin{abstract}
Abstrak
Penelitian ini bertujuan untuk melihat apakah ada pengaruh dari variabel the big five personality terhadap kinerja pegawai Badan Penanggulangan Bencana Daerah di DIY. Jumlah sampel yang digunakan sebanyak 98 pegawai. Teknik pengambilan sampel yang digunakan adalah kuesioner. Penelitian ini bersifat kuantitatif dengan pendekatan survei dan teknik analisis menggunaka software SPSS 17. Hasil analisis menunjukkan bahwa the big five-personality secara bersama-sama tidak berpengaruh terhadap kinerja pegawai BPBD DIY. Setelah dilakukan analisis tambahan perdimensi big five-personalitydan perdimensi kinerja ditemukan hasil bahwa ada pengaruh positif antara perdimensi conscientiousness dengan perdimensi kinerja efektif efisien dan pengaruh positif dimensi extraversion terhadap dimensi kinerja disiplin. Implikasi manajerial yang dapat dilakukan berkaitan dengan peningkatan kinerja pegawai diantaranya variabel conscientiousness dan extraversion memiliki peran yang paling tinggi pada kinerja pegawai khususnya pada dimensi efektif efisien dan dimensi disiplin pada BPBD DIY diantara variabel lainnya yang tidak memiliki pengaruh terhadap kinerja BPBD DIY. Variabel tersebut perlu diperhatikan oleh pihak manajerial BPBD DIY khususnya bidang pengembangan sumberdaya manusia karena kepribadian conscientousnes dan extraversion merupakan karakter yang tertanam pada diri pegawai khususnya dimensi efektif dan efisien untuk keberhasilan sebuah organisasi sehingga pihak manajerial BPBD DIY dianjurkan untuk menciptakan kepribadian conscientousnes dan extraversion dikalangan pegawai untuk menunjang tingkat efektif efisian dan tingkat kedisiplinan pegawai.
\end{abstract}

Kata kunci: big five personality, kinerja pegawai, efektif-efisien, disiplin

Abstract
This research aims to see whether there is influence from The Big Five personality variable on the
performance of employees of the Regional Disaster Management Agency in DIY. The number of
samples used was 98 employees. The sampling technique used was a questionnaire. This research is
quantitative with a survey approach and analysis techniques using SPSS 17 software. The results of
the analysis show that the big five personality together does not affect the performance of RDMA DIY
employees. After an additional analysis of big five personality dimensions and performance dimensions
was found the results showed that there was a positive influence between conscientiousness dimension
and the dimensions of effective efficient performance and the positive effect of extraversion dimensions
on the dimensions of discipline performance. The managerial implications that can be made relating
to improving employee performance include the conscientiousness and extraversion variables that
have the highest role in employee performance, especially in the efficient effective dimension and
disciplinary dimensions of RDMA DIY among other variables that have no influence on the
performance of RDMA DIY. These variables need to be considered by RDMA DIY managerial, especially
in the field of human resource development because conscientiousness and extraversion personality
are employee-embedded characters especially effective and efficient dimensions for the success of an
organization so that the RDMA DIY managerial is encouraged to create conscientous and extraversion
personality among employees to support the effective level of efficiency and level of discipline of
employees.
Keywords: big five personality, employee performance, effective-efficiency, discipline




\section{PENDAHULUAN}

Berdasarkan perda Daerah Istimewa Yogyakarta (DIY) Nomor 10 Tahun 2010 tentang organisasi dan tata kerja Badan Penanggulangan Bencana Daerah (BPBD) Daerah Istimewa Yogyakarta dan peraturan gubernur nomor 55 Tahun 2010 tentang rincian tugas Badan Penanggulangan Bencana Daerah (BPBD) Daerah Istimewa Yogyakarta, tugas tersebut adalah; Merumuskan kebijakan penyelenggaraan penanggulangan bencana di daerah dengan cepat, tepat, efektif dan efisien; Mengkoordinasikan dan melaksanakan penyelenggaraan penanggulangan bencana di daerah secara terencana, terpadu dan menyeluru; dan melaksanakan pengelolaan kegiatan-kegiatan penanggulangan bencana.

Terkait dengan potensi bencana alam, penanggulangan bencana memegang peranan yang sangat penting, baik pada saat sebelum, saat, dan sesudah terjadinya bencana. Penanggulangan bencana diarahkan pada bagaimana mengelola risiko bencana sehingga dampak bencana dapat dikurangi atau dihilangkan. Secara geologis Daerah Istimewa Yogyakarta (DIY) merupakan salah satu wilayah di Indonesia yang rawan terhadap bencana alam. Data bencana tahun 2017 yang tercatat Badan Penanggulangan Bencana Daerah (BPBD) DIY mencapai 1.065 kejadian. "Laporan kejadian mencapai 1.970, kejadian bencana mencapai 1.065," Menurut Manajer Pusdalops BPBD DIY, Danang Samsu Rizal.

Pada kegiatan penilaian kinerja instansi yang dilakukan oleh pemerintah Daerah Istimewa Yogyakarta (DIY) secara berkala, terdapat beberapa instansi yang kinerja organisasinya tidak mengalami peningkatan bahkan terjadi penurunan. Hal ini tentu dapat berpengaruh secara tidak langsung terhadap kinerja pemprov Daerah Istimewa Yogyakarta (DIY).

Pada website bkd.jogjaprov.go.id dapat kita lihat bahwa Badan Penanggulangan Bencana Daerah (BPBD) Daerah Istimewa Yogyakarta berada di posisi 4 terbawah yaitu pada posisi ke33 dengan nilai 852,88 dan posisi ke-34 dengan nilai 859,45 pada tahun 2016 dan 2017 yang menunjukkan bahwa salah satu instansi yang tidak mengalami peningkatan prestasi kerja bahkan tergolong rendah dari 37 instansi pemerintah. Hal ini tentu saja dapat menimbulkan kecemasan dan keprihatinan pada pemerintah DIY karena pada tahun 2016 pemerintah memberikan rangsangan reward yang diberikan berupa tambahan penghasilan selama kurang lebih 2 tahun ternyata dapat dikatakan belum mampu meningkatkan kinerja instansi Badan Penanggulangan Bencana Daerah (BPBD) pemerintah Daerah Istimewa Yogyakarta (DIY). Selain itu apabila mengacu pada ketentuan UU nomor 5 Tahun 2014 yang memandang bahwa gaji harus dapat memacu produktivitas, maka tampaknya tujuan tersebut masih belum dapat dicapai oleh Badan Penanggulangan Bencana Daerah (BPBD) pemerintah Daerah Istimewa Yogyakarta (DIY).

Faktanya dalam wawancara awal dengan kepala bagian pusdalapos Danang Samsul Rizal menyatakan beban kerja dengan intensitas yang beragam serta lingkungan kerja yang tidak kondusif dapat menimbulkan penurunan kinerja pegawai. Berdasarkan data pegawai BPBD DIY terdapat 98 pegawai yang bekerja di BPBD DIY.

Kinerja di tentukan oleh beberapa faktor diantaranya faktor lingkungan dan faktor personal kepribadian. Menurut Robbins (1996), kepribadian big five Kinerja ditentukan oleh beberapa faktor diantaranya adalah beban kerja dan kepribadian the big five personality, dimensi kepribadian tersebut antara lain (Robbins, 1998:55) kemantapan emosional (neouriticsm), ekstraversi (extraversion), keterbukaan terhadap pengalaman (openness to experience), mampu bersepakat (agreeableness), mendengarkan kata hati (conscienctousness).

Berdasarkan hasil riset penelitian sebelumnya faktor kepribadian juga mempengaruhi kinerja seseorang. Indarti, Hendriani dan Mahda (2014) menyatakan bahwa banyak peneliti 
yang menganggap kepribadian merupakan salah satu faktor psikologi yang mempengaruhi kinerja. Hal ini dikarenakan kepribadian memberikan garis panduan umum yang dapat membimbing ke kinerja yang efektif. Untuk itulah, maka langkah-langkah yang dilakukan untuk meningkatkan kinerja pegawai sangat diperlukan. Oleh karena itu peneliti tertarik mengambil topik penelitian di Badan Penanggulangan Daerah (BPBD) Daerah Istimewa Yogyakarta. Dalam penelitian ini, kepribadian big five-personalitydigunakan sebagai variabel yang mempengaruhi kinerja pegawai Badan Penanggulangan Bencana Daerah DIY.

\section{TINJAUAN PUSTAKADAN PERUMUSAN HIPOTESIS}

\section{Kinerja}

"Performance is defined as the record of outcomes produced on a specified job function or activity during time period". Prestasi atau kinerja adalah catatan tentang hasil-hasil yang diperoleh dari fungsi-fungsi pekerjaan tertentu atau kegiatan selama kurun waktu tertentu (Bernardin dan Russel, 2002:15). Menurut Gibson, (2003:355), job performance adalah hasil dari pekerjaan yang terikat dengan tujuan organisasi, efisiensi dan kinerja keefektifan kinerjalainnya.

\section{Kinerja Individu}

Kinerja pada dasarnya adalah apa yang dilakukan atau tidak dilakukan oleh pegawai. Kinerja adalah hasil kerja secara kualitas dan kuantitas yang dicapai oleh seorang pegawai dalam melaksanakan tugasnya sesuai denga tanggung jawab yang diberikan kepadanya (Mangkunegara, 2001: 67). Kinerja dapat diartikan dengan outcome atau hasil sebuah pekerjaan atas peran serta pegawai dalam suatu organisasi. Dengan demikian kinerja lebih pada capaian tugas yang terukur pada kurun waktu yang ditentukan, yang terdiri dari produktivitas kerja, komitmen, loyalitas, sikap dan perilaku, serta usaha pengembangan diri. Menurut Mangkunegara (2001: 68) bahwa karakterikstik orang yang mempunyai kinerja tinggi adalah sebagai berikut: 1) Memiliki tanggung jawab pribadi yang tinggi; 2) Berani mengambil dan menanggung resiko yang dihadapi; 3) Memiliki tujuan yang realistis; 4) Memiliki rencana kerja yang menyeluruh dan berjuang untuk merealisasi tujuannya; 5) Memanfaatkan umpan balik (feed back) yang konkrit dalam seluruh kegiatan kerja yang dilakukannya; 6) Mencari kesempatan untuk merealisasikan rencana yang telah diprogramkan.

\section{Faktor Penentu Kinerja}

Tuntutan akan kinerja pegawai yang tinggi memang sudah menjadi bagian dari semua instansi pemerintahan. Namun fakta yang ada sekarang memperlihatkan bahwa belum semua pegawai memiliki kinerja yang tinggi sesuai dengan harapan instansi pemerintahan. Oleh karena itu untuk dapat meningkatkan kinerja, maka salah satu hal yang perlu diperhatikan oleh seorang pegawai adalah faktor kepribadian. faktor kepribadian tersebut antara lain neouriticism, extraversion, openness to experience, agreeableness, conscientiousness.

\section{Kepribadian}

Kepribadian meliputi beberapa karakteristik yang membuat seseorang menjadi unik (Joseph, 2011). Berbagai dimensi dapat digunakan untuk mempelajari dan mengevaluasi kepribadian, tetapi satu hal yang menjadi kesepakatan dari beberapa penelitian tersebut adalah bahwa tidak ada dua individu yang benar-benar identik. 


\section{Kepribadian The Big Five}

John, Donahue dan kentle (1991) mendeskripsikan lima besar dimensi kepribadian sebagai Neouriticism ditandai dengan mudah bingung dan merupakan kebalikan dari emotional stability. Extraversionditandai dengan banyak bicara dan penuh semangat. Oppeness to experience ditandai dengan orisinalitas, keingintahuan dan kecerdikan. Conscientiousness ditandai dengan keteraturan, tanggung jawab dan kehandalan, kadang juga disebut dependability. Agreeableness ditandai dengan baik hati, kemauan untuk bekerja sama dan kepercayaan.

Dimensi-dimensi kepribadian big five tersebut adalah neouriticism, extraversion, openness to experience agreeableness, conscientiousness; Neouriticism dikenal sebagai instabilitas emosional, dimensi kepribadian yang mengacu pada kecenderungan untuk mengalami emosi negatif. Neouriticism diidentikan dengan sebuah kecenderungan untuk mudah mengalami situasi tidak menyenangkan seperti marah, gelisah tertekan, dan mudah bersedih hati; Extraversion, yaitu dimensi kepribadian yang ditandai dengan keterikatan nyata dengan dunia luar. Yuwono (2005: 93-94) menyatakan dimensi kepribadian ini mencakup tingkat kesenangan seseorang dalam menjalin interaksi. Orang yang ekstravert cenderung suka berkelompok, tegas, dan mampu bersosialisasi dalam kelompok: senang berbicara, menonjolkan diri, dan mencari perhatian untuk diri sendiri; Openness to experience diidentikan dengan intelektualitas, kemampuan kognitif yang tinggi, kreatif dan konsekuen.

Menurut sinha (2007:1) openness to experience tidak mempunyai pengaruh signifikan terhadap kinerja. Individu yang terbuka terhadap hal-hal yang baru adalah orang yang kreatif, ingin tahu, dan sensitif secara artistic; Agreeableness menurut Yuwono (2005:26-34) yaitu dimensi ini menunjukkan kecenderungan individu untuk bersepakat dengan orang lain dan mudah mempercayai orang lain. Individu ber-agreeable tinggi memiliki pandangan optimis terhadap sifat manusia, yakni percaya bahwa pada dasarnya orang-orang baik hati, sopan, dan dapat dipercaya (Goldberg, 1993: 26-34); Conscientiousness, yaitu dimensi kepribadian yang menyangkut cara seseorang mengawasi, mengatur, dan mengarahkan dorongan hati. Individu dengan tingkat conscientiousness tinggi dicirikan sebagai pribadi yang bertanggung jawab, terorganisir, dapat dipercaya, dan gigih (Yuwono, 2005:93-94). Sinha (2007:1).

\section{Dampak kepribadian big five terhadap kinerja}

Kepribadian conscientiousness merupakan prediktor yang tepat bagi tercapainya kinerja terbaik untuk semua jenis pekerjaan. Kepribadian merupakan aspek kajian yang sangat penting mengenai perilaku dalam lingkungan organisasi. Riset mengenai kepribadian big five telah menemukan hubungan antara kepribadian dengan kinerja (Robbins, 1996: 89). Kemampuan individu untuk bertahan terhadap pekerjaannya dengan lingkungan pekerjaannya tergantung pada keberhasilan mereka dalam mengadaptasikan kepribadian dengan lingkungan pekerjaannya. Individu dengan kepribadian yang sesuai dengan tuntutan lingkungan kerjanya akan merasa diterima dalam organisasi. Namun, individu dengan kepribadian yang tidak sesuai dengan tuntutan lingkungan kerjanya dihadapkan pada dua pilihan, yaitu berusaha adaptif atau menarik diri dari organisasi tersebut dan bergabung dengan organisasi lain yang lebih sesuai tuntutannya. Ini menunjukkan bahwa kepribadian individu merupakan salah satu faktor penentu efektivitas kerja untuk meraih tujuan organisasi. Berdasarkan pendekatan kepribadian tersebut, dimungkinkan pegawai dengan kepribadian yang tidak sesuai dengan kepribadian pegawaiakan mengalami penurunan kinerja karena merasa beban kerja yang terlalu tinggi. 


\section{Perumusan Hipotesis}

Pada penelitian ini terdapat 5 hipotesis pengaruh the big five personalityterhadap kinerja. Dengan memperhatikan hasil penelitian yang berdasarkan pada penelitian sebelumnya mengenai pengaruh big five personality terhadap kinerja maka peneliti merumuskan hipotesis penelitian sebagai berikut;

\section{H1 Terdapat Pengaruh Negatif Tipe Kepribadian Neouroticism Terhadap Kinerja pegawai BPBD DIY}

Neouriticism diidentikan dengan sebuah kecenderungan untuk mudah mengalami situasi tidak menyenangkan seperti marah, gelisah tertekan, dan mudah bersedih hati. Persoalan dalam pengaturan emosi dapat mengurangi kemampuan neorotic untuk berfikir jernih, membuat keputusan, dan mengatasi stres secara efektif. Kecenderungan untuk mengembangkan gejalagejala ketakutan dan depresi, ditandai dengan kecenderungan-kecenderungan obsesi mudah tersinggung, apatis, labil, perasaan yang mudah terluka, mudah gugup, menderita rasa rendah diri, mudah melamun, dan sukar tidur. Individu neourotis berintelegensi tinggi, teliti tetapi lambat dan keras kepala. Pegawai dalam menyelesaikan suatu pekerjaan tertentu yang notabene pekerjaannya bersifat rutinitas, menumpuk dan sedang dalam mengalami suasana hati yang tidak baik maka pemilik tipe kepribadian neouriticism rendah tingkat kinerjanya karena kecenderungan untuk mudah mengalami situasi tidak menyenangkan seperti marah, gelisah tertekan, dan mudah bersedih hati membuat pegawai tersebut tidak bersemangat dan cenderung bermalas-malasan dalam bekerja. Ninien (2015) dalam penelitian yang berjudul : Pengaruh kecerdasan emosi, Big FivePersonality Traits Terhadap Kinerja Layanan dari staff Course Consultant di EF English Fisrt EdukaGroup Surabaya. Hasil analisa penelitian ini adalah variabel big fivepersonality traits tidak berpengaruh pada kinerja karyawan di EF English First Edukagroup.

\section{H2 Terdapat Pengaruh Positif Tipe Kepribadian Extraversion Terhadap Kinerja pegawai BPBD DIY.}

Extraversion identik dengan energik, emosi positif, bergelora atau bersemangat, dan suka berkelompok. Yuwono (2005: 93-94) menyatakan dimensi kepribadian extraversion mencakup tingkat kesenangan seseorang dalam menjalin interaksi. Orang yang ekstravert cenderung suka berkelompok serta mampu bersosialisasi dalam kelompok: senang berbicara, menonjolkan diri, dan mencari perhatian untuk diri sendiri dan tegas.

Sebuah organisasi membutuhkan pegawai yang aktif dalam berinteraksi dengan pegawai lain untuk memudahkan kordinasi terhadap sesama pegawai dalam menyelesaikan sebuah pekerjaan dan perasaan memiliki semangat dalam bekerja karena tipe kepribadian extraversion yang mudah beradaptasi dan bergaul dengan siapa saja. Hal tersebut dapat membuat pegawai tidak bermalas-malasan dan memiliki kualitas kinerja yang tinggi.

H3 Terdapat Pengaruh Positif Tipe Kepribadian Opennessto experience Terhadap Kinerja pegawai BPBD DIY

Openness to experience diidentikan dengan intelektualitas, kemampuan kognitif yang tinggi, konsekuen dan kreatif. Pegawai dengan kreatifitas tinggi, intelektualitas tinggi dan kemampuan kognitif yang tinggi akan cenderung memiliki kinerja yang tinggi hal ini karena kreatifitas akan ide-ide baru yang dimiliki oleh pegawai tersebut untuk menyelesaikan suatu pekerjaan dengan keterampilan tertentu yang memudahkan pegawai dalam menyelesaikan tugas. Sehingga, 
seseorang dengan keterbukaan imajinatif dan penuh wawasan, mereka mampu melihat visi untuk masa depan organisasi (Judge dan Bono, 2004).

\section{H4 Terdapat Pengaruh Positif Tipe Kepribadian Agreeableness Kinerja pegawai} BPBD DIY

Agreeableness menurut Yuwono (2005:26-34) menyatakan dimensi ini menunjukkan kecenderungan individu untuk tunduk dan bersepakat dengan orang lain. Hal ini selaras dengan penelitian yang telah dilakukan oleh Rinaldi (2008) yakni bahwa agreeableness memiliki hubungan yang signifikan dengan kinerja karyawan PT Perusahaan Perdagangan Indonesia. Dengan demikian karyawan PT Perusahaan Perdagangan Indonesia bisa bekerja dengan saling membantu baik secara individu maupun kelompok, memiliki perasaan saling percaya serta simpatik terhadap partner kerjanya karena dapat dikatakan kualifikasi pekerjaan yang dilakukan karyawan memiliki tendensi membutuhkan sisi agreeableness pada proses kerja dan pola interaksi. Hal ini juga diperkuat dengan pernyataan bahwa agreeableness merupakan kepribadian yang menunjukan kesenangan untuk bekerja sama dengan orang lain, berkaitan dengan aspek kepercayaan, fleksibilitas, kooperatif, dan toleransi (Neuman, Wagner, \& Christiansen, 1999).

\section{H5 Terdapat Pengaruh Positif Tipe Kepribadian Conscientiousness Terhadap Kinerja pegawai BPBD DIY.}

Conscientiousness, menurut Sinha (2007:1) individu conscientiousness merupakan pekerja yang produktif dan kinerjanya tinggi, karena seseorang yang memiliki sifat teliti (Conscientiousness) cenderung memiliki pengarahan yang kuat dan bekerja keras untuk meraih tujuan. Individu yang conscientiousness berorientasi pada sasaran dan detail, mereka cenderung terlibat dalam manajemen dengan aktif, mereka dapat diandalkan dan tidak mungkin untuk mengelak dari tanggung jawab pekerjaan, mereka juga tidak mungkin menunjukkan perilaku kepemimpinan pasif yang mana meliputi kurangnya disiplin diri dan standar tanggung jawab kepemimpinan (Judge dan Bono, 2004). Hal ini selaras dengan penelitian yang telah dilakukan oleh Carl J.Thoresen, et.al (2004) yang berjudul The Big Five Personality Traits and Individual Job Performance Growth Trajectories in Maintenance and Transitional Job Stages, kepribadian memiliki pengaruh positif secara signifikan terhadap kinerja.

\section{Gambar 1. Kerangka Hipotesis Penelitian}

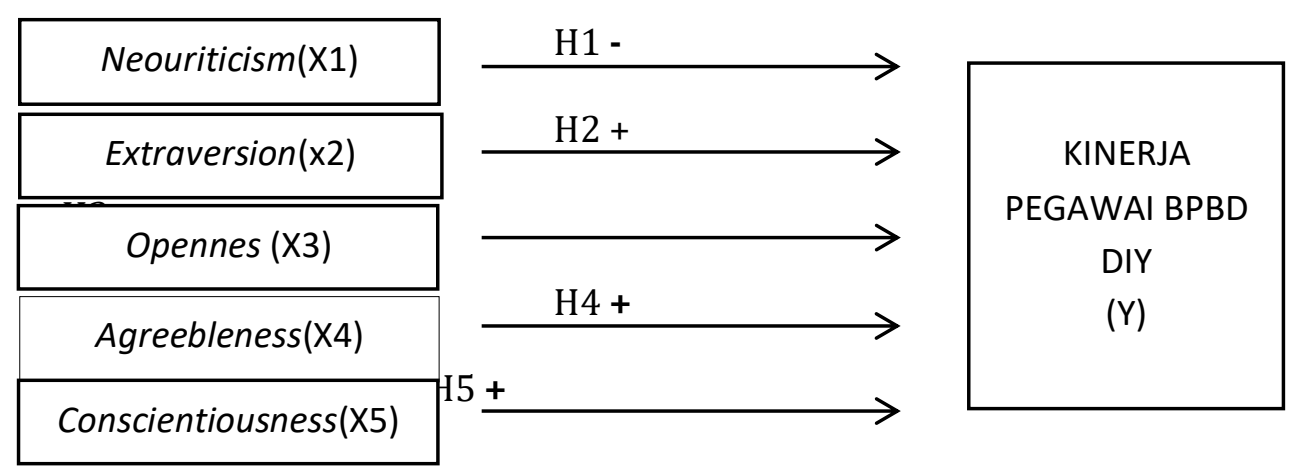

\section{METODE PENELITIAN}

Jenis Penelitian ini adalah penelitian kuantitatif dengan pendekatan metode survei. Metode pengambilan sampel pada penelitian ini menggunakan teknik sampel jenuh, teknik pengambilan 
sampel dengan melibatkan semua anggota populasi sebagai sampel. Penelitian ini di lakukan di Badan Penanggulangan Bencana Daerah (BPBD) Daerah Istimewa Yogyakarta beralamat di Jalan Kenari No. 14A, Semaki, Umbulharjo, Kota Yogyakarta, Daerah Istimewa Yogyakarta, Kode Pos 55166. Obyek dari penelitian ini adalah BPBD DIY merupakan kepanjangan dari Badan Penanggulangan Bencana Daerah, Daerah Istimewa Yogyakarta. Populasi dalam penelitian ini adalah seluruh pegawai yang bekerja di Badan Penanggulangan Bencana Daerah DIY. Subyek penelitian sebanyak 98 orang.

Untuk mendukung dalam pelaksanaan penelitian ini, ditinjau dari sumbernya, data penelitian dibagi menjadi dua jenis yaitu bahan atau materi yang dipergunakan berupa data primer maupun data sekunder yang berhubungan dengan obyek penelitian. Dalam pengumpulan data, digunakan beberapa teknik, yaitu: 1) Kuesioner atau angket adalah sejumlah pertanyaan tertulis yang diperlukan untuk memperoleh informasi dari responden. Kuesioner merupakan teknik pengumpula data yang dilakukan dengan cara memberi seperagkat pertanyaan atau pertanyaan tertulis kepada responden untuk dijawab (Sugiyono, 2004)., 2) Dokumentasi adalah teknik pengumpulan data dengan cara mempelajari, berbagai dokumen resmi, seperti data, peraturan-peraturan dan buku-buku yang memiliki referensi yang jelas dengan masalah yang hendak diamati.

Variabel dalam penelitain ini terdiri dari variabel bebas (X) dan variabel terikat (Y). Variabel bebas (independent) adalah the big five personality dalam penelitian ini terdiri dari: neouriticism (X1), extraversion (X2), openness to experience (X3), agreeableness (X4), Conscientiosness (X5). Variabel terikat dalam penelitian ini adalah: Kinerja pegawai (Y) Menurut menurut Chester I. Barnard Indikator-indikator kinerja pegawai adalah sebagai berikut (2008:27-32): Efektivitas dan efisiensi, otoritas dan tanggung jawab, disiplin, inisiatif. Instrumen yang digunakan dalam penelitian ini adalah kuesioner yang disusun dalam penelitian sebelumnya dengan beberapa sedikit perubahan pertanyaan penelitian.

Uji coba kuesiner bertujuan untuk mengetahui apakah alat ukur yang digunakan sudah mengukur apa yang harus di ukur oleh alat tersebut, yaitu kuesioner (Nasution, 2001). Validitas adalah suatu ukuran yang menunjukan tingkat kevalidan dan kesahihan suatu instrumen (Arikunto 1998: 168). Untuk mengetahui apakah kuesioner yang digunakan valid atau tidak, maka $r$ yang diperoleh (rhitung) dikonsultasikan dengan (rtabel) maka instrumen dikatakan valid, dan apabila rhitung > rtabel maka instrumen dikatakan valid, dan apabila rhitung < rtabel maka instrumen dikatakan tidak valid. pada penelitian ini, uji validitas dilakukan dengan menggunakan bantuan program SPSS.

Uji reliabilitas bertujuan untuk menetapkan apakah instrumen dapat digunakan lebih dari satu kali untuk jawaban lebih dari 2 (Umar, 2010). Reliabilitas adalah instrumen cukup dipercaya untuk digunakan sebagai alat pengumpul data karena instrumen itu sudah baik (Arikunto 1998, h.170).

Reliabilitas damaksudkan untuk mengetahui seberapa tingkat konsistensi internal (intenal consistency) jawaban responden terhadap instrumen untuk mengukur variabel big five, dan kinerja pegawai (Eko Aria 2008: 50). Suatu instrumen pengukuran yang menghasilkan koefisien alpha cronbach kurang dari 0,6 dipertimbangkan kurang baik, 0,7 dapat diterima dan diatas 0,8 baik (Eko Aria 2008: 50). Uji reliabilitas dalam penelitian ini dilakukan dengan menggunakan bantuan program SPSS.

Dalam penelitian ini skala pengukuran yang digunakan adalah skala likert. Untuk analisis data kuantitatif, maka jawaban responden diberi skor 1-5. 


\section{HASIL PENELITIAN DAN PEMBAHASAN}

\section{Uji Validitas Kuesioner}

Uji validitas kuesioner pada penelitian ini menggunakan analisis korelasi product moment dengan $\mathrm{df}=\mathrm{n}-2$ dan alpha $=0,05$.

\section{Variabel neouriticism (X1)}

menunjukkan nilai keseluruhan nilai $r$ hitung lebih besar dari $r$ tabel $(d f=n-2),(\alpha 0.05,98)$. Berdasarkan data tersebut dapat disimpulkan bahwa setiap butir pernyataan pada kuesioner neouriticism terbukti valid.

\section{Variabel Extraversion (X2)}

menunjukkan nilai keseluruhan nilai $r$ hitung lebih besar dari $r$ tabel $(d f=n-2),(\alpha 0.05,98)$. Berdasarkan data tersebut dapat disimpulkan bahwa setiap butir pernyataan pada kuesioner Extraversion terbukti valid.

\section{Variabel Openess to experience (X3)}

menunjukkan nilai $r$ hitung butir Menyukai Kerja Rutinitas dan Tertarik pada Seni lebih kecil dari $r$ tabel $(\mathrm{df}=\mathrm{n}-2),(\alpha 0.05,98)$ sehingga item tersebut digugurkan dari pengukuran statistik. Sedangkan item lainnya dalam kuisioner openess to experience terbukti valid.

\section{Variabel agreebelness (X4)}

Hasil perhitungan uji validitas menjelaskan bahwa nilai $r$ hitung item Mencari Kesalahan Orang Lain pada penelitian ini lebih kecil dari dari $r$ tabel $(d f=n-2),(\alpha 0.05,98)$ sehingga item tersebut digugurkan. Item lainya terbukti valid karena $r$ hitung lebih besar dari $r$ tabel.

\section{Variabel consientiousness (X5)}

Hasil perhitungan uji validitas menjelaskan bahwa nilai $r$ hitung dari Urakan atau Tidak Teratur lebih kecil dari $r$ tabel dari $r$ tabel $(\mathrm{df}=\mathrm{n}-2),(\alpha 0.05,98)$ sehingga item tersebut digugurkan. Item lainya pada kuisioner conscientiousness terbukti valid karena lebih besar dari $r$ tabel sehingga dapat dilanjutkan sebagai bahan analisis.

\section{Uji validitas kinerja pegawai $(\mathrm{Y})$}

Perhitungan uji validitas kinerja (efektif efisien) menghasilkan adanya 3 item yang tidak valid yakni Berjiwa Kepemimpinan, Cermat dan Konsisten sehingga item tersebut digugurkan. Perhitungan selanjutnya menggunakan data item kuisioner lainnya yang dinyatakan valid.

Perhitungan uji validitas kinerja (tanggung jawab) menunjukkan adanya 1 item yang tidak valid yakni Dapat Diandalkan sehingga item tersebut digugurkan. Perhitungan selanjutnya menggunakan data item kuisioner lainnya yang dinyatakan valid.

Perhitungan uji validitas pada kinerja disiplin menunjukkan adanya 1 item yang tidak valid yakni Taat Pada Aturan sehingga item tersebut digugurkan. Perhitungan selanjutnya menggunakan data item kuisioner lainnya yang dinyatakan valid.

Perhitungan uji validitas pada kinerja (inisiatif) menunjukkan adanya 4 item yang tidak valid yakni Inisiatif Tugas, Memberikan Ide Kreatif, Memanfaatkan Feed Back, Bekerja Mandiri sehingga item tersebut digugurkan. Perhitungan selanjutnya menggunakan data item kuisioner lainnya yang dinyatakan valid.

\section{Uji Reliabilitas Kuesioner}

Tabel 1.1 Uji Reliabilitas

\begin{tabular}{lccc}
\hline \multicolumn{1}{c}{ Variabel } & $\begin{array}{c}\text { AlphaCronbach } \\
\text { Coefficient }\end{array}$ & Cut of Value & Keterangan \\
\hline The Big FivePersonality & 0.646 & 0,600 & Reliabel \\
Kinerja & 0.724 & 0,600 & Reliabel \\
\hline
\end{tabular}


Tabel 1.1 uji reliabilitas menunjukan masing-masing nilai koefisien Alpha Cronbach variabel pada kuesioner penelitian ini lebih dari Cut of Value uji reliabilitas menggunakan Cronbach Alpha yakni 0.600 sehingga dapat disimpulkan bahwa setiap butir pernyataan yang termuat dalam kuesioner penelitian ini merupakan butir yang reliabel dan dapat digunakan dalam penelitian.

\section{Neouriticsm berpengaruh negatif terhadap kinerja}

Berdasarkan hasil penelitian ini analisis regresi variabel neouriticsm terhadap kinerja menghasilkan nilai koefisien regresi sebesar -392 dengan tingkat signifikan 0,204. Nilai signifikansi tersebut lebih besar dari $p$-value yaitu 0,05 maka hipotesis 1 pada penelitian ini tidak terbukti.

\section{Extraversion berpengaruh positif terhadap kinerja}

Analisis regresi yang dilakukan antara variabel bebas extraversion (X2) menghasilkan koefisien regresi sebesar -892 dengan tingkat signifikansi $0,004 \quad(<0,05)$ sehingga hasil tersebut menunjukkan adanya pengaruh negatif dari variabel extraversion terhadap kinerja sebsesar 892 secara signifikan. Berdasarkan hal tersebut dapat disimpulkan bahwa hipotesis 2 yang menyatakan extraversion berpengaruh positif terhadap kinerja tidak di dukung dalam penelitian ini sehingga hipotesis tersebut tidak diterima.

\section{Openess to Experience berpengaruh positif terhadap kinerja}

Analisis regresi dari variabel openess to experience terhadap kinerja menghasilkan koefisien regresi sebesar 0,016 dengan nilai signifikan $0,951(>0,05)$. Hal tersebut berarti pada penelitian ini openess to experience tidak memiliki pengaruh yang signifikan terhadap kinerja sehingga hipotesis 3 tidak didukung oleh hasil penelitian ini.

\section{Agreeableness berpengaruh positif terhadap kinerja}

Hasil analisis regresi pada hubungan antara variabel agreeableness terhadap kinerja sebesar 0.018 dengan tingkat signifikansi $0,817(>0,05)$. Nilai signifikan tersebut menunjukkan bahwa variabel agreeableness pada penelitian ini tidak memiliki pengaruh yang signifikan terhadap kinerja sehingga hipotesis 4 pada penelitian ini ditolak.

\section{Consientiousness berpengaruh positif terhadap kinerja}

Perhitungan analisis regresi Consientiousness terhadap kinerja memiliki nilai 0,252 dengan tingkat signifikan sebesar 0,362 $(>0,05)$. Berdasarkan hasil tersebut maka variabel Consientiousness pada penelitian ini tidak memiliki pengaruh yang signifikan terhadap kinerja sehingga hipotesis ke-5 pada penelitian ini tidak didukung oleh hasil penelitian.

\section{PEMBAHASAN}

\section{Pengaruh Neouriticism Terhadap Kinerja Pegawai BPBD DIY}

Penelitian ini menemukan adanya pengaruh negatif dari neouriticism terhadap kinerja pegawai BPBD DIY tetapi tidak signifikan. Hal ini disebabkan karena sebagian besar bidang pekerjaan di BPBD DIY bukanlah suatu pekerjaan rutinitas atau hal yang diulang-ulang terutama pada bagian pekerja lapangan jadi meskipun seorang pegawai BPBD memiliki emosi yang labil, namun karena pekerjaan lapangan yang cenderung berbeda beda pekerjaannya maka emosinya cenderung akan membaik dan tidak akan mengganggu kinerjanya. Sedangkan untuk pegawai BPBD yang memiliki pekerjaan bersifat rutin terutama pekerja yang berada dikantor jika pegwai tersebut memiliki emosi yang labil maka hal itu akan mengganggu kinerjanya karena pekerjaan yang rutin cenderung membuat emosi seseorang menjadi memburuk. Penelitian ini sejalan dengan penelitian Arief tri wicaksono pada PT. Gresik. Penelitian ini sesuai dengan kondisi karyawan PT Gresik Cipta Sejahtera merasa khawatir tidak dapat mencapai target sesuai dengan 
perusahaan maka dari itu kekhawatiran ini berdampak pada kinerja karyawan yang kurang optimis dalam mencapai targetnya.

\section{Pengaruh Extraversion Terhadap Kinerja Pegawai BPBD DIY Pengaruh Extraversion Terhadap Kinerja Pegawai BPBD DIY}

Penelitian ini menemukan tidak ada pengaruh yang positif dari extraversion terhadap kinerja pegawai Badan Penanggulangan Bencana Daerah Istimewa Yogyakarta. Hal ini disebabkan karena kebanyakan jenis pekerjaan di BPBD DIY erat kaitannya dengan aktifitas fisik terutama dibagian pekerjaan lapangan, dimana kepribadian seseorang tidak memiliki pengaruh yang signifikan terhadap jenis pekerjaan seperti ini. Jadi meskipun seseorang memiliki kepribadian extraversion yang tinggi hal itu tidak berpengaruh signfikan terhadap tingkat kinerja pegawai BPBD. Penelitian ini sejalan dengan penelitian Jun Surjanti, Ekstraversi tidak berpengaruh secara signifikan terhadap kinerja pegawai. Hal ini dikarenakan Setiap bulan setiap pegawai memiliki target yang sudah di tentukan oleh organisasi, sehingga karyawan akan berusaha mencapai targetnya sendiri. Sehingga dalam pekerjaan karyawan lebih individual.

\section{Pengaruh Openness To ExperienceTerhadap Kinerja Karyawan BPBD DIY}

Penelitian ini menemukan tidak ada pengaruh yang positif dari openness to experience terhadap kinerja pegawai Badan Penanggulangan Bencana Daerah Istimewa Yogyakarta. Hal ini disebabkan karena tipe-tipe pekerjaan yang ada di BPBD mayoritas sudah memiliki cara-cara yang paten, sehingga tingkat openness to experience pegawainya tidak berpengaruh kepada hasil kinerja, sebagai contoh; pekerjaan lapangan seperti mengambil sampel pengamatan aktifitas gunung berapi sudahmemiliki cara-cara dan aturan yang bersifat baku dan wajib di laksanakan sehingga tidak memerlukan kreatifitas ataupun inventif (inovasi-inovasi) dari pegawainya. Penelitian ini sejalan dengan penelitian Sinha (2007:1) openness to experience tidak mempunyai pengaruh signifikan terhadap kinerja.

\section{Pengaruh Agreeableness terhadap kinerja karyawan BPBD DIY}

Penelitian ini menemukan tidak ada pengaruh yang positif dari agreeableness terhadap kinerja pegawai Badan Penanggulangan Bencana Daerah Istimewa Yogyakarta. Agreeableness tidak berpengaruh secara signifikan terhadap kinerja Hal ini sesuai dengan yang terdapat pada BPBD DIY bahwa pegawai cenderung mudah bersepakat dengan pegawai lain atau kebijakan pada organisasi BPBD DIY tanpa berpikris kritis terhadap pendapat yang disampaikan. Contoh lain; meskipun seorang pegawai memiliki sifat tertutup hal itu tidak berpengaruh terhadap kinerja pegawai BPBD DIY, jadi pegawai memiliki sifat tertutup ataupun terbuka masih dapat bekerja masing-masing dengan baik. Penelitian ini sejalan dengan Arif Wicaksono, agreebalenness tidak mempunyai pengaruh signifikan terhadap kinerja karyawan pada perusahaan PT.Gresik Sejahtera karena karyawan cenderung mudah bersepakat untuk mengikuti aturan yang sudah dibuat oleh perusahaan tersebut.

\section{Pengaruh conscientousness terhadap kinerja karyawan BPBD DIY}

Penelitian ini menemukan tidak ada pengaruh yang positif dari neouriticism terhadap kinerja pegawai Badan Penanggulangan Bencana Daerah Istimewa Yogyakarta. hal ini ditunjukkan dengan pegawai BPBD DIY merasa bahwa setiap pekerjaan adalah sebuah kewajiban yang mereka harus kerjakan. Jadi meskipun setiap aparatur sipil Negara atau pegawai memiliki sifat yang ceroboh, pemalas, sulit berkonsentrasi hal ini tidak akan menghalangi tanggung jawabnya pada sebuah pekerjaan yang harus diselesaikan sesuai tugasnya masing-masing pegawai.Penelitian ini sejalan dengan penelitian Irnawati Ninien (2015) kepribadian conscientousnness tidak mempunyai pengaruh signifikan terhadap kinerja. 


\section{Analisis Tambahan regresi dimensi Bigfive terhadap dimensi kinerja}

Tabel 2.1 menunjukkan hasil perhitungan masing-masing variabel independen terhadap dimensi variabel dependen.

Tabel 2.1 analisis regresi perdimensi

\begin{tabular}{lcccccccc}
\hline \multirow{2}{*}{ Big five } & \multicolumn{9}{c}{ Kinerja } \\
\cline { 2 - 10 } & \multicolumn{2}{c}{ Efektif-efisien } & \multicolumn{2}{c}{ Tanggung } & \multicolumn{2}{c}{ Disiplin } & \multicolumn{2}{c}{ Inisiatif } \\
\cline { 2 - 10 } & $\mathrm{B}$ & Sig & $\mathrm{B}$ & Sig & $\mathrm{B}$ & Sig & $\mathrm{B}$ & Sig \\
\hline Neouriticism & 0,17 & 0,849 & 0,17 & 0,849 & 0,20 & 0,727 & $-0,249$ & 0,158 \\
Extraversion & -131 & 0,121 & $-0,221$ & 0,66 & $-0,126$ & 0,025 & $-0,154$ & 0,375 \\
Openess to & $-0,18$ & 0,806 & $-0,34$ & 0,741 & 0,011 & 0,824 & $-0,040$ & 0,786 \\
Agreeablenes & $-0,82$ & 0,442 & $-0,67$ & 0,644 & 0,029 & 0,675 & 0,164 & 0,432 \\
Consientiousn & $-0,188$ & 0,015 & 0,82 & 0,645 & 0,048 & 0,361 & 0,228 & 0,155 \\
\hline
\end{tabular}

Hasil pada tabel 4.26 tersebut menunjukkan bahwa analisis yang memiliki nilai yang signifikan yakni pada analisis Consientiousness (X5)terhadap dimensi efektif-efisien dengan nilai koefisien regresi sebesar -0,188 dengan signifikansi 0,015 $(<0,05)$ artinya variabel tersebut memiliki pengaruh negatif secara signifikan. Analisis variabel Extraversion (X2) terhadap disiplin memiliki koefisien regresi sebesar -0,126 dengan signifikansi 0,025 $(<0,05)$ maka variabel tersebut hasil tersebut memiliki pengaruh negatif yang signifikan. Hasil analisis regresi lainya tidak memiliki nilai signifikan atau dapat dikatakan bahwa variabel indepenen tidak memiliki pengaruh terhadap variabel dependen.

\section{Pengaruh dimensi kepribadian Conscientiousnes terhadap kinerja khususnya dimensi efektif dan efisien}

Hasil penelitian ini terbukti bahwa variabel conscientiousness berpengaruh signifikan terhadap variabel kinerja khususnya dimensi efektif dan efisien pada BPBD DIY. Kepribadian Conscientiousness ditandai dengan keteraturan, tanggung jawab dan kehandalan. hasil penelitian ini memiliki kesesuaian dengan kepribadian conscientiousness yakni pegawai BPBD DIY yang memiliki kepribadian conscientiousness akan memiliki ketrampilan khusus untuk menyelesaikan pekerjaan dengan tepat waktu, teliti, serta cermat dalam bekerja, dalam melakukan pekerjaan jarang melakukan suatu kesalahan, mampu menyelesaikan tugas yang diberikan dengan konsisten, serta menentukan dan mengatur prioritas kerja secara efektif dan efisien. Secara keseluruhan hasil penelitian ini konsisten dengan penelitian Althoff (2010) yang menunjukkan conscientiousness adalah prediktor terbaik. Temuan ini kemungkinan karena kesamaan antara skala orang yang merencanakan dan memprioritaskan tugas dan terlibat dalam kegiatan berorientasi tujuan terkait dengan domain conscientiousness yakni efektif efisien, tepat waktu, disiplin diri, dan keseluruhan domain tersebut didedikasikan untuk tugas.

\section{Pengaruh dimensi kepribadian ekstraversion terhadap kinerja khususnya dimensi disiplin}

Hasil penelitian ini menemukan bahwa variabel ekstraversion berpengaruh signifikan terhadap kinerja khususnya pada dimensi disiplin. Kepribadian Extraversion dicirikan dengan emosi positif, mudah bergaul, bersemangat, suka berkelompok. Salah satu aspek kekuatan SDM dapat tercermin pada sikap dan perilaku disiplin sebab disiplin mempunyai dampak yang kuat terhadap suatu organisasi untuk mencapai keberhasilan dalam mengejar tujuan yang direncanakan. kedisiplinan merupakan fungsi operatif manajemen SDM yang paling penting karena semakin baik disiplin pegawai maka semakin tinggi juga prestasi atau kinerja yang dicapainya. Kinerja yang baik adalah kinerja yang optimal yaitu kinerja yang sesuai dengan standar organisasi. Hasil penelitian ini sesuai dengan penelitian McCrae (1992) energi yang terlihat pada seseorang yang tingkat extraversion nya tinggi dapat membantu mempertahankan kedisiplinan pengendalian diri hal ini diperlukan untuk memulai dan menyelesaikan sebuah proyek. 


\section{KESIMPULAN}

Neouriticsm memiliki pengaruh negatif tetapi tidak signifikan terhadap kinerja pegawai BPBD DIY Yogyakarta. Extraverison tidak memiliki pengaruh terhadap kinerja pegawai BPBD DIY Yogyakarta. Openess to experience tidak memiliki pengaruh terhadap kinerja pegawai BPBD DIY Yogyakarta Agreeableness tidak memiliki pengaruh terhadap kinerja pegawai BPBD DIY Yogyakarta. Consientiousness tidak memiliki pengaruh terhadap kinerja pegawai BPBD DIY Yogyakarta.

Analisis yang memiliki nilai yang signifikan yakni pada analisis Consientiousness (X5)terhadap dimensi efektif-efisien dengan nilai koefisien regresi sebesar -0,188 dengan signifikansi $0,015(<0,05)$ artinya variabel tersebut memiliki pengaruh negatif secara signifikan. Analisis variabel Extraversion(X2) terhadap disiplin memiliki koefisien regresi sebesar -0,126 dengan signifikansi 0,025 $(<0,05)$ maka variabel tersebut hasil tersebut memiliki pengaruh negatif yang signifikan. Hasil analisis regresi lainya tidak memiliki nilai signifikan atau dapat dikatakan bahwa variabel indepenen tidak memiliki pengaruh terhadap variabel dependen.

\section{IMPLIKASI MANAJERIAL}

Penelitian ini menunjukkan bahwa pengaruh dari variabel conscientiousness dan extraversion memiliki peran yang paling tinggi pada kinerja pegawai khususnya pada dimensi efektif efisien dan dimensi disiplin pada BPBD DIY. Variabel tersebut perlu di perhatikan oleh pihak manajerial khususnya bidang sumber daya manusia. Pihak manajerial dalam melakukan seleksi pribadi dianjurkan mengutamakan kepribadian conscientiousness dan extraversion yang ada pada calon pegawai untuk menunjang kinerja pegawai. Saran untuk pihak manajerial untuk pegawai yang sudah menjalankan tugas di BPBD DIY adalah menerapkan program pengembangan karakter untuk menstimulasi kepribadian conscientiousness dan extraversion terhadap pegawai BPBD DIY.

\section{SARAN UNTUK PENELITIAN SELANJUTNYA}

Penambahan variabel eksternal untuk melihat kinerja pegawai BPBD DIY sehingga memperluas lingkup penelitian dengan topik terkait dapat dipertimbangkan untuk penelitian yang selanjutnya. Menggunakan instrumen penggalian informasi dengan sistem wawancara pribadi adalah saran yang baik untuk mengeksplorasi jawaban lebih luas terhadap setiap individu dari variabel-variabel terkait. Eksplorasi variabel conscientiousness yang masih sangat luas dapat menjadi lahan penelitian dalam rangka pengembangan keilmuan. Dalam pengembangan penelitian sebaiknya menambah sudut pandang misalnya meminta pendapat bagian pengembangan sumberdaya manusia (HRD) organisasi dalam menilai pegawai sehingga tidak hanya dari sudut pandang pegawai/ meminta laporan kinerja pegawai BPBD per Tahun. Tesis ini hanyalah sebatas tulisan teoritis yang dirangkai melalui penarikan persepsi dan asumsi berdasarkan alat uji spss dan penalaran logika penulis. Sehingga kebenarannya masih akan banyak ditemukan atau mungkin ketidaksamaan anggapan dengan para pembaca dalam hal penulisan dan analisis, oleh karena itu pembaca berhak menilai dengan penilaian akademis apapun terhadap karya ini, karya ini diharapkan memberikan sumbangsih terhadap perkembangan ilmu terutama dalam bidang ekonomi dan sumber daya manusia.

\section{DAFTAR PUSTAKA}

Arikunto, S. (2006). Prosedur Suatu Pendekatan Praktik. Jakarta: Rineka Cipta.

Cahyanto, A. (2012). Pengaruh Tingkat Kepribadian Terhadap Tingkat Absensi Pegawai Pada Kantor Pelayanan Utama Bea dan Cukai Tipe A Tanjung Priok. Yogyakarta: Tesis. Fakultas Ekonomika dan Bisnis Universitas Gadjah Mada.

Definisi Beban Kerja. (1997). Retrieved April 24, 2018, from Menpan: http://www.bkn.go.id 
Faisal, A. H. (2015). Analisis Pengaruh Penilaian Kinerja, Motivasi Kerja, dan Beban Kerja Terhadap Kinerja Auditor Internal Lippo Group. Yogyakarta: Tesis. Prodi Magister Akuntansi Universitas Gadjah Mada.

Fitriyanti, E. N. (2017). Evaluasi Beban Kerja dan Kebutuhan Tenaga Kerja Pada Pelayanan Dispensing Obat di Depo Utama Rawat Jalan Instalasi Farmasi RSAB Harapan Kita. Yogyakarta: Tesis. Prodi Ilmu Kesehatan Masyarakat, Magister Manajemen Rumah Sakit Universitas Gadjah Mada.

Gosling, S. R. (2003). A Very Brief Measure of The Big Five Personality Domains. Journal Research in Personality 37, 504-528.

Ilyas, Y. (2014). Perencanaan SDM Rumah Sakit, Teori Metoda dan Formula. Depok: Pusat Kajian Ekonomi Kesehatan Fakultas Kesehatan Masyarakat, Universitas Indonesia.

Jacson, M. (2010). Human Resource Management. USA: South-Western: Cengage Learning.

John, O. \&. (1999). The Big Five Trait Taxonomy History, Measurement, and Theoritical Perspectives in Handbook Personality, Theory and Research. Second Edition Edited by Lawrence A. Pervin, and Oliver P. John (pp. 102-139). New York: The Guildfordpress.

John, 0. D. (1991). The Big Five Inventory Versions 4a and 5a, Berkeley. CA: University of California, Berkeley Institute of Personality and Social Research.

Joseph, T. D. (2011). Personality, Trait, Sex and Age of Inmates in Nigerian Prisons. Europen Journal of Educational Studies 3, 1.

Mahsun, M. (2016). Pengukuran Kinerja Sektor Publik (Edisi Pertama). Yogyakarta: Penerbit BPFE.

Mathis, e. a. (2006). Human Resources Management Edisi ke Sepuluh . Jakarta: Salemba.

Maulina, R. W. (2016). Pelaksanaan Kesehatan dan Keselamatan Kerja (K3) Bagi Petugas Operasional Badan Penanggulangan Bencana Daerah (BPBD) Kota Yogyakarta. Yogyakarta: Tesis. Prodi Hukum Perdata Fakultas Hukum Universitas Gadjah Mada (Tidak dipublikasikan.

Nasional, T. P. (2005). Kamus Besar Bahasa Indonesia (Edisi Ketiga). Jakarta: Balai Pustaka.

Nawasi, H. (2010). Manajemen Sumber Daya Manusia. Yogyakarta: Gadjah Mada University Press.

Panggalo, I. (2017). Analisis Pengaruh Keadilan Prosedural Persepsian Dalam Sistem Penilaian Kinerja, Kepuasan Kerja, dan Beban Kerja Terhadap Kinerja Auditor PT Bank Profesional. Yogyakarta: Tesis. Progi Magister Manajemen Universitas Gadjah Mada.

Putra, R. S. (2016). Analisis Pengaruh Shift Kerja Terhadap Beban Kerja Mental Pemandu Lalu Lintas Penerbangan Untuk Menentukan Jumlah Operator Optima;. Yogyakarta: Tesis. Prodi Teknik Industri Fakultas Teknik Universitas Gadjah Mada.

Ramdhani, N. (2012). Adaptasi Bahasa dan Budaya Inventori Big Five. Jurnal Pskiologi Fakultas Psikologi Universitas Gadjah Mada, 189-207.

Rinaldi. (2008). Hubungan Antara Dimensi Kepribadian Big Five dengan Stress Kerja Pengajar Perguruan Tinggi. Yogyakarta: Prodi MM Jurusan Ilmu-ilmu Sosial Fakultas Ekonomika dan Bisnis Universitas Gadjah Mada.

Robbins, S. P. (1996). Perilaku Organisasi: Konsep, Kontroversi, Aplikasi. Terjemahan oleh Hadyana Pujaatmaka. Jakarta: Prenhallindo. 
Sinha, K. (2007). How Much Does Personality Influence Job Performance? New York: Rochester Institute of Technology.

Stromer, S. \&. (2010, May). Individual Determinants of Work Attendance: Evidence on The Role of The Personality. IZA discussion Paper Series No. 4927.

Sugiyono. (2004). Metode Penelitian Bisnis. Bandung: Alfabeta.

Suranto, d. L. (2004). Metodologi Penelitian untuk Ekonomi dan Bisnis. Yogyakarta: UPP Akademi Manajemen Perusahaan YKPN.

Walshe, k. d. (2006). Healthcare Management Edisi Kedua. England: Open University Press.

Winata, N. E. (2015). Evaluasi Pemberian Tambahan Penghasilan Pegawai (TPP) Studi Kasus Pada Instansi BPBD Prov Daerah Istimewa Yogyakarta. Yogyakarta: Tesis. Prodi Magister Administrasi Publik Universitas Gadjah Mada.

Yuwono, I, F. S. (2005). Psikologi Industri dan Organisasi. Surabaya: Jurnal. Fakultas Psikologi Universitas Airlangga.

Mangkunegara, A.A. Anwar Prabu (2004). Manajemen Sumber Daya Manusia Cetakan Pertama. Bandung: PT Remaja Rosda. 